\title{
A Constituição Brasileira de 1988 e seus princípios estruturantes
}

Gilmar Antonio Bedin* Joicemar van Der Sand**

\section{INTRODUÇÃO}

A Constituição de 1988 é fundamentalmente marcada por diversas especificidades e tem como grande referência ser uma Carta Magna reconhecida como "Constituição cidadã”. Essa marca deve-se ao fato que é uma constituição democrática e popular, eis que se originou de um órgão constituinte composto por representantes do povo na Assembleia Nacional Constituinte de 1987. Esse fato pôs fim a mais de duas décadas do regime militar e da Constituição Autoritária de 1967/69.

Assim, neste novo cenário de democracia, a constituição é instituída por um conjunto de dispositivos destinados a estabelecer as bases políticas, sociais, administrativas e jurídicas da república brasileira, denominados princípios fundamentais da constituição. Esses princípios são o princípio da república, da federação, da divisão dos poderes e do Estado Democrático de Direito.

Como república, a Constituição busca a garantia do aspecto público do Estado e da coisa pública, numa visível separação com os bens e interesses dos particulares, isto é, o Estado, através dos seus agentes, deve agir no interesse público, prestando satisfação dos seus atos e não se guiando por interesses particulares de quem quer que dele possa tentar se apropriar, em detrimento do interesse coletivo. Como federação, a divisão do Estado brasileiro em estados-membros, dotados de autonomia para gerir e buscar seus interesses de acordo com a vontade de seus habitantes (nos limites definidos pela Constituição Federal), pretende facilitar a administração das diversidades regionais, a desconcentração do poder político e

* Doutor em Direito do Estado pela Universidade Federal de Santa Catarina - UFSC. Professor permanente dos Programas de Pós-Graduação em Direito da Universidade Regional do Noroeste do Estado do Rio Grande do Sul (UNIJUÍ) e da Universidade Regional Integrada do Alto Uruguai e das Missões (URI - Santo Ângelo).

** Mestre em Direito pelo Programa de Pós-Graduação Stricto Sensu da Universidade Regional Integrada do Alto Uruguai e das Missões (URI - Santo Ângelo). Advogado. 
a aproximação entre governantes e governados. Como um Estado com divisão de poderes, o Estado brasileiro se firma como uma democracia substantiva e como uma ordem política voltada à moderação. Já como Estado Democrático de Direito, a constituição estabelece a forma da efetivação das relações entre os indivíduos e o Estado, qual seja, através das leis elaborada a partir da anuência da população, que a estabelece direta ou indiretamente por meio dos seus representantes.

O presente trabalho tem como objetivo fundamental a apresentação dos referidos princípios estruturantes da ordem constitucional brasileira. Dito de outra forma, se propõe a apresentar os alicerces sobre os quais se constrói o nosso ordenamento jurídico pátrio. A ideia é demostrar a importância de tais pressupostos muitas vezes negligenciados na análise da Constituição e de seu conteúdo. O método de pesquisa utilizado na elaboração do trabalho foi o hipotético-dedutivo e a técnica de pesquisa utilizada a da pesquisa bibliográfica.

\section{O PRINCÍPIO DA REPÚBLICA}

República é um conceito romano, como democracia é um termo grego. Vem da res publica, coisa pública. Surgiu em Roma substituindo a monarquia, mas monarquia e república não se definem pelo mesmo critério. Monarquia se define por quem manda: significa o poder (arquia) de um (mono) só. Já a palavra república não indica quem manda, e sim para que manda. O poder aqui está a serviço do bem comum, da coisa coletiva ou pública. Ao contrário de outros regimes, e em especial da monarquia, na república não se busca a vantagem de um ou de poucos, mas a do coletivo (RIBEIRO, 2001, p. 18).

Por isso, uma das expressões mais utilizadas no vocabulário jurídico é o princípio republicano. Embora conhecido, em muitas ocasiões não é adequadamente compreendido, pois é utilizado a partir de conceitos insuficientes ou parciais. Esta falta de compreensão do princípio republicano, prejudica o perfeito entendimento de termos como direitos fundamentais e cidadania, por exemplo. Ao mesmo tempo, deturpa o sentido da democracia que deve ser entendida como um instrumento republicano, ou seja, uma ferramenta para atingirmos o interesse da maioria e sua aplicação nos mais diversos aspectos sociedade brasileira.

Da obra de Gomes Canotilho (2003, p. 229) extraímos a seguinte caracterização do conceito republicano de governo:

a) A primeira dimensão jurídico-constitucional do sistema republicano de governo é a radical incompatibilidade de um governo republicano com o princípio monárquico e com os privilégios hereditários (dimensão antiaristocrática);

b) O segundo aspecto é a exigência de uma estrutura político-organizatória garantidora das liberdades cívicas e políticas. A forma republicana de 
governo não é tanto ou não é primordialmente uma 'forma antimonárquica' mas um esquema organizatório de controle do poder;

c) Em terceiro lugar, a forma republicana pressupõe um regime de liberdade onde se articulem intersubjetivamente a liberdade dos antigos (direito de participação política) e a liberdade dos modernos (direitos de defesa individuais);

d) A forma republicana de governo aponta também para a existência de corpos territoriais autônomos (administração autônoma) que pode legitimar tanto um esquema territorial de natureza federativa ou de autonomia regional como de autarquias locais de âmbito territorial mais restrito;

e) A forma republicana de governo reivindica uma legitimação do poder político baseada no povo ('governo do povo'). Num governo republicano a legitimidade das leis funda-se no princípio democrático com a consequente articulação da autodeterminação do povo com o 'governo de leis' e não 'governo de homens';

f) A forma republicana de governo recolhe e acentua a ideia 'antiprivilégio' no que respeita à definição dos princípios e critérios ordenadores do acesso à função pública e aos cargos públicos. Dá-se preferência aos critérios da eletividade, colegialidade, temporariedade e pluralidade, aos critérios da designação, hierarquia e vitaliciedade.

Assim, a menção de república se denota numa forma de governo pautada no princípio constitucional a conformar o contexto como um todo do ordenamento jurídico. De acordo com Geraldo Ataliba (2004, p. 65): “a simples menção ao termo república já evoca um universo de conceitos intimamente relacionados entre si, sugerindo a noção do princípio jurídico que a expressão quer designar".

Para Renato Janine Ribeiro (2001, p. 64), a república está associada ao direito. A modernidade em política constrói duas grandes obras. Uma é a democracia. A outra, mais antiga, avançando desde a Renascença, é o Estado de direito - ou seja, a ideia de obedecer à lei e não ao arbítrio do poderoso. Em tese, o Estado de direito não precisa ser democrático. Uma aristocracia de magistrados honestos poderia aplicar imparcialmente a lei. É o que se chama de império da lei, rule of law. Mas essa consagração da lei acima dos interesses particulares já significa que ela é coisa pública e não privada. Há aí o princípio republicano da prioridade conferida à res pública.

Isso vem ao encontro do princípio republicano ter sido fundamentalmente mantido e destacado na Constituição de 1988, já que pontua não só a forma de governo, como também se refere a própria organização estatal e o relacionamento deste com os cidadãos. Como república, pretende a constituição garantir o aspecto público do Estado e das coisas que lhe tocam (coisa pública), ou seja, 
uma clara separação com os bens e interesses dos particulares. O Estado deve agir no interesse público, mediante responsabilidade dos agentes estatais, prestando satisfação de seus atos e não se guiando por interesses particulares.

Nesse contexto, podemos considerar o princípio republicano como princípio reitor de nosso ordenamento jurídico, pois dele derivam todos os demais princípios constitucionais, assim como as demais normas jurídicas existentes e válidas. Por ocupar esse lugar jurídico estratégico, o princípio de república está previsto no Art. 1º da Carta Magna de 1988.

$\mathrm{O}$ verdadeiro significado do princípio republicano permite que se estabeleçam hipóteses e que se possam propor desdobramentos para todo o direito público, com uma compreensão mais segura do conteúdo, sentido e alcance de todos os seus institutos. A República é uma espécie de síntese de todas as instituições. Nesse sentido, Fábio Konder Comparato (2006, p. 12) esclarece que a verdadeira república, conforme nos mostraram claramente os romanos, é um regime no qual o bem comum do povo sempre está acima de interesses particulares, de famílias, classes, grupos religiosos, sindicatos e, até mesmo, entidades estatais.

No mesmo sentido, Celso Lafer (1989, p. 214-224), afirma que está presente no conceito de república a ênfase ao bem público, que não deve ser confundido com o interesse particular, pois esse sim é a antítese da coisa pública. Nesse contexto, Renato Janine Ribeiro (2001, p. 32) destaca: qual o cerne, então, da república? A definição de monarquia destaca quem exerce o poder, e a de república para que serve o poder. Na monarquia manda um, e na república o poder é usado para o bem comum. Assim, embora quando um único mande e ele tenda usar o poder em benefício próprio, a verdadeira ameaça à república está nesse uso do poder, e não na forma institucional: está nos fins, e não nos meios.

Assim, o princípio republicano possui íntima relação com o regime político republicano, que define que seus agentes exerçam funções políticas em representação ao povo, devendo decidir em nome desse e a ele se submeter no que se refere à satisfação do interesse público, cumprindo o mandato que lhe é outorgado. Dessa forma, são características da república a eletividade, a periodicidade e a responsabilidade.

O princípio republicano, portanto, implica na necessária legitimidade popular do presidente da república, dos governadores de estados e do distrito federal e dos prefeitos municipais, através de eleições periódicas por tempo determinado, ou seja, na temporariedade dos mandatos e não vitaliciedade dos cargos políticos.

Por isso, na atual ordem constitucional, esse princípio desempenha a função imprescindível de garantir estruturas para a concretização de todos os demais princípios constitucionais, ou seja, é matriz de todos os outros princípios. Roque Antônio Carrazza (2011, p. 81) leciona que: "república é o tipo de governo, fundado na igualdade formal das pessoas, em que detentores do poder político 
exercem-no em caráter eletivo, representativo (de regra), transitório e com responsabilidade".

Nesse sentido, importante a lição de Ribeiro (2001, p. 69), afirmando que:

Governo, porém, não é o mesmo que poder. Na democracia, o poder é do povo, ainda que a administração ou governo se delegue a representantes. O importante não é todos governarem, o que é impossível, mas o povo controlar seus representantes. Quanto maior o controle popular, mais democrático o poder. Isso porque, quanto mais as pessoas forem virtuosas - isto é, ciosas de distinguir o bem comum dos interesses privados - maior será sua participação no poder, nem que seja de fora, verificando, discutindo, cobrando; ou seja, quanto mais republicanas forem as pessoas, participando, mais democrático será o poder.

Assim, podemos afirmar que o princípio republicano possui uma vertente política e uma vertente principiológica, onde a vertente política trata da forma de governo e a principiológica é aquela que define a igualdade dos cidadãos perante o estado, já que este pertence a todos. Por esse motivo, o princípio republicano não se resume apenas à eleição dos representantes do povo, por um mandato renovável periodicamente, mas implica também a igualdade de acesso dos cidadãos aos cargos públicos, eletivos ou não, preenchidos os requisitos legais, além de contemplar a progressiva superação das causas da pobreza e dos fatores de marginalização, simultaneamente à supressão dos privilégios de todo o gênero.

\section{O PRINCÍPIO DA DIVISÃO DOS PODERES}

Na doutrina de José Afonso da Silva (2014, p. 108) o princípio da divisão de poderes é um princípio geral do direito constitucional que a Constituição inscreve como um dos princípios fundamentais que ela adota. $\mathrm{O}$ artigo $2^{\circ}$ define que são poderes da União, independentes e harmônicos entre si, o Legislativo, o Executivo e o Judiciário. Essa expressão dos três poderes exprime duplo sentido: as funções legislativa, executiva e jurisdicional e o respectivos órgãos, conforme descritos e discriminados no título IV, da organização dos poderes.

Para melhor compreensão deste princípio, algumas considerações sobre o poder são importantes. Segundo o autor, o poder é um fenômeno sociocultural, que significa que é um fato da vida social. Pertencer a um grupo social é reconhecer que ele pode exigir certos atos ou conduta, de acordo com os fins perseguidos; é admitir que pode nos impor certos esforços, sacrifícios, que pode fixar limites e prescrever determinadas formas às nossas atividades.

Assim, o Estado, como grupo social máximo e total, também possui o seu poder, que é o poder político ou estatal. A sociedade estatal, chamada 
também sociedade civil, compreende uma multiplicidade de grupos sociais e indivíduos diferenciados, aos quais o poder político tem que coordenar e impor regras e limites em função dos fins globais que o Estado cumpre realizar. Daí a constatação que o poder político é superior a todos os outros poderes sociais, os quais reconhece, rege e domina visando a ordenar as relações entre esses grupos e indivíduos, de maneira a manter um mínimo de ordem e estimular o máximo de progresso à vista do bem comum. Essa superioridade do poder político caracteriza a soberania do Estado, que implica, por um lado, independência com todos os poderes exteriores à sociedade estatal (soberania externa) e supremacia sobre os poderes sociais interiores à mesma sociedade estatal (soberania interna) (SILVA, 2014, p. 109).

Os órgãos do Estado são supremos (constitucionais), a quem incumbe o exercício do poder político, ou seja, os órgãos governamentais ou governo e os órgãos dependentes (administrativos), num plano hierárquico inferior, cujo conjunto forma a administração pública, considerados de natureza administrativa (SILVA, 2014, p. 109).

O governo é, então, o conjunto de órgãos através dos quais a vontade do Estado é formulada, expressada e realizada ou o conjunto de órgãos responsáveis pelas funções do poder político. Vale dizer, portanto, que o poder político uno, indivisível e indelegável - se desdobra e se compõe de várias funções, fato que permite falar em distinção de funções, que fundamentalmente são três: a legislativa, a executiva e a jurisdicional (SILVA, 2014, p. 110).

A função legislativa consiste na edição de regras gerais, abstratas, impessoais e inovadoras da ordem jurídica, o que denominamos leis. A função executiva resolve os problemas concretos e individualizados, de acordo com as leis; não se limita à simples execução das leis, comporta prerrogativas, e nela entram todos os atos e fatos jurídicos que não tenham caráter geral e impessoal. Já a função jurisdicional tem por objeto aplicar o direito aos casos concretos a fim de dirimir conflitos de interesses (SILVA, 2014, p. 110).

O princípio da separação de poderes já foi descrito na obra do filósofo iluminista Montesquieu (2000, p. 181), afirmando que essa separação se deve ao fato de que tudo estaria perdido se o mesmo homem ou o mesmo corpo dos principais ou dos nobres, ou do povo, exercesse esses três poderes: o de fazer as leis, o de executar as resoluções públicas e o de julgar os crimes ou as divergências dos indivíduos. Nessa situação de concentração de poderes não haveria liberdade política nem controle mútuo e recíproco entre os poderes estatais, o que resultaria em despotismo, tirania, arbitrariedade e opressão por parte dos que ocupassem as funções estatais carentes de separação, nocivos tanto ao próprio Estado quanto aos direitos fundamentais dos cidadãos (governados).

Por isso, esse princípio foi sempre um princípio fundamental do ordenamento constitucional brasileiro e que foi mantido na Constituição de 1988 ao adotar o sistema tripartite de Montesquieu, conforme o Art. $2^{\circ}$, da carta 
magna. Nessa concepção tripartite, todos os poderes previstos neste artigo têm suas competências ou funções discriminadas no texto constitucional, de modo que a regra é a harmonia entre os poderes, como prevê o texto maior.

Necessário destacar que o poder estatal não se confunde com as funções estatais, pois estas funções são abrigadas pelo princípio da separação de poderes e não aquele poder político. Nesse sentido, Dirley da Cunha Júnior (2010, p. 515) leciona que:

O poder político, como fenômeno sociocultural, é uno e indivisível, uma vez que aquela "capacidade de impor", decorrente de seu conceito, não pode ser fracionada. Embora realidade única, ele manifesta-se por meio de funções, que são, fundamentalmente, de três ordens, a saber: a executiva, a legislativa e a judiciária. Essas funções, por muito tempo, houve-se concentradas junto a determinado organismo estatal. $O$ fenômeno da separação de Poderes não é senão o fenômeno da separação das funções estatais, que consiste na forma clássica de expressar a necessidade de distribuir e controlar o exercício do Poder político entre distintos órgãos do Estado. O que corretamente, embora equivocadamente, se convencionou chamar de separação de Poderes, é, na verdade, a distribuição e divisão de determinadas funções estatais a diferentes órgãos do Estado. Deveras, como o poder é uno e incindível, não há falar em separação de Poderes, mas, sim, em separação de funções do Poder político ou simplesmente de separação de funções estatais. Insistimos: não é o poder que é divisível, mas, sim, as funções que o compõem e se manifestam por distintos órgãos do Estado.

Assim sendo, além da divisão de funções do poder político, revela-se necessário, no dizer de Dirley da Cunha Júnior (2010, p. 522), que "essas distintas funções sejam exercidas por órgãos também distintos, da forma a mais especializada possível, todos situados num mesmo plano, sem haver qualquer relação de subordinação entre eles”. Além disso, afirma ser imprescindível que:

os Poderes Legislativo, Executivo e Judiciário sejam desempenhados por órgãos diferentes, "de maneira que, sem nenhum usurpar as funções dos outros, possa cada qual impedir que os restantes exorbitem da sua esfera própria de ação". Só assim é possível o controle do poder pelo poder, só assim é possível a plena realização da separação de Poderes, que se traduz - sintetizamos - na separação funcional (cada função deve ser confiada a cada órgão da maneira mais especializada possível) e na separação orgânica (os órgãos da soberania devem ter independência mútua e devem estar, em tudo, em idêntico pé de igualdade). É essa a essência da doutrina da separação de Poderes. (CUNHA JÚNIOR, p. 522). 
Portanto, o princípio da separação dos poderes denota que esta separação é assentada na independência e harmonia entre os órgãos do poder político, o que resulta na inexistência de qualquer relação de subordinação ou dependência com relação aos poderes legislativo, executivo e judiciário, relacionado ao exercício de suas funções e, ao mesmo tempo, no estabelecimento de um mecanismo de controle mútuo entre tais poderes. Neste contexto, não cabe ao poder executivo e legislativo desobedecer a ordem do poder judicial, nem a este e ao executivo descumprirem as leis instituídas pelo poder legislativo, nem ao judiciário e ao legislativo interferirem no regular exercício das funções reservadas ao poder executivo.

Ainda conforme Cunha Júnior (2010, p. 527), essa independência entre os poderes não significa exclusividade no exercício das funções que lhe são atribuídas, mas, sim, predominância no seu desempenho. Embora, baseado na clássica tríplice divisão funcional, as funções legislativas, executivas e judiciais sejam exercidas predominantemente pelos próprios poderes (funções típicas), os poderes também desempenham, de modo subsidiário, outras funções típicas dos outros poderes (funções atípicas), que também servem para garantir a sua própria autonomia e independência. Diante disso, o princípio da separação dos poderes deve ser compreendido como:

um meio a proporcionar, tanto quanto possível, não uma separação rígida de funções, mas, sim, uma coordenação, colaboração ou um entrosamento entre as distintas funções estatais, numa relação de interdependência, de modo a permitir que cada Poder, ao lado de suas funções típicas ou principais, correspondentes à sua natureza, possa, em caráter secundário, colaborar com os demais, ou desempenhar funções que, teoricamente, não pertencem ao seu âmbito de competência, mas ao de outro Poder, desde que, para tanto, não seja sacrificado o seu núcleo essencial. (CUNHA JÚNIOR, p. 527).

Sobre essa independência dos poderes consagrados pela constituição, também destacamos as lições de José Afonso da Silva asseverando que:

A independência dos poderes significa: (a) que a investidura e a permanência das pessoas num órgão do governo não dependem da confiança nem da vontade dos outros; (b) que, no exercício das atribuições que lhes sejam próprias, não precisam os titulares consultar os outros nem necessitam de sua autorização; (c) que, na organização dos respectivos serviços, cada um é livre, observadas apenas as disposições constitucionais e legais; assim é que cabe ao Presidente da República prover e extinguir cargos públicos da Administração federal, bem como exonerar ou demitir seus ocupantes, enquanto é da competência do Congresso Nacional ou dos Tribunais prover os cargos dos respectivos serviços administrativos, exonerar ou demitir seus ocupantes; às Câmaras 
do Congresso e aos Tribunais compete elaborar os respectivos regimentos internos, em que se consubstanciam as regras de seu funcionamento, sua organização, direção e polícia, ao passo que o Chefe do Executivo incumbe a organização da Administração Pública, estabelecer seus regimentos e regulamentos. Agora, a independência e autonomia do Poder Judiciário se tornaram ainda mais pronunciadas, pois passou para a sua competência também a nomeação dos juízes e tomar outras providências referentes à sua estrutura e funcionamento, inclusive em matéria orçamentária (arts. 95, 96, e 99) (SILVA, 2014, p. 112).

Nesse contexto, o que se observa no estado moderno é que a distribuição tripartite não mais aceita um modelo de estado dotado de poderes totalmente independentes, reclamando uma atuação eficaz e harmônica, inclusive com mecanismos que possibilitem a efetivação dos direitos fundamentais, que, em último recurso cabe ao poder judiciário, quando provocado, adotar medidas para que estes direitos não se traduzam apenas em meros enunciados sem qualquer eficácia.

Sobre essa questão da harmonia entre os poderes, José Afonso da Silva afirma que:

\begin{abstract}
A harmonia entre os poderes verifica-se primeiramente pelas normas de cortesia no trato recíproco e no respeito às prerrogativas e faculdades a que mutuamente todos têm direito. De outro lado, cabe assinalar que nem a divisão de funções entre os órgãos do poder nem a sua independência são absolutas. Há interferências, que visam ao estabelecimento de um sistema de freios e contrapesos, à busca do equilíbrio necessário à realização do bem da coletividade e indispensável para evitar o arbítrio e o demando de um em detrimento do outro e especialmente dos governados (SILVA, 2014, p. 112).
\end{abstract}

Fica claro, portanto, que apesar de os poderes do Estado serem independentes e autônomos devem também ser harmônicos entre si, ou seja, não há que se falar em supremacia de um poder em relação a outro poder estatal. Assim, deve existir a divisão dos poderes, mas também deve estar presente a ideia que os referidos poderes devem ser harmônicos. Esse é um dos grandes princípios estruturantes da ordem constitucional em vigor no Brasil.

\title{
3. O PRINCÍPIO DA FEDERAÇÃO
}

Outro princípio fundamental e estruturante da nossa república, é, justamente, o princípio federativo, esculpido na Constituição de 1988 em seus artigos $1^{\circ}$ e 18 , também elevado a condição de cláusula pétrea, através do art. 60, $\$ 4^{\circ}$, I, da Carta Magna. Esse princípio define a forma de Estado, ao observar a 
sua organização fundamental, ou seja, nasce com a aliança entre os estados, com isso, denota a soberania perante o direito internacional, ao passo que os estados membros são autônomos para o direito interno.

Como Federação, o estado, ao dividir-se em porções administrativas menores, dotadas de autonomia para buscar seus interesses e regular-se conforme a vontade de seus habitantes (obedecendo os ditames da constituição federal), busca a uma maior facilidade na administração das diversidades regionais, a desconcentração do poder político e a aproximação entre governantes e governados, ou seja, o princípio federativo define a forma de Estado que é a federação, mas por outro lado o estado não deixa de ser unitário.

Assim podemos afirmar que a federação é a forma de Estado na qual há mais de uma esfera de poder dentro de um mesmo território e sobre uma mesma população. Os membros integrantes da nossa federação (união, estados-membros, distrito federal e municípios) não possuem soberania, mas apenas desfrutam de autonomia deferida diretamente pela constituição, diferentemente da soberania, que corresponde a um quadro interno de competências, rigidamente demarcadas pela Carta Magna.

Portanto, na análise do conceito de federação, o que mais interessa éa noção de autonomia, pois a federação só existe quando, em razão da descentralização política, as ordens passam a usufruir de autonomia no mesmo território, por serem previstas constitucionalmente como competências próprias.

Todavia, um aspecto que não pode ser confundido ao se falar em autonomia é a diferença com a soberania. A autonomia se refere a forma de Estado e a soberania diz respeito ao povo, finalidade e território, é um elemento constitutivo do próprio Estado. Ao discorrer sobre essa questão, José Afonso da Silva assevera que:

No Estado Federal há que se distinguir soberania e autonomia e seus respectivos titulares. Houve muita discussão sobre a natureza jurídica do estado Federal, mas, hoje, já está definido que o Estado Federal, o todo, como pessoa reconhecida, pelo Direito internacional, é o único titular da soberania, considerada poder supremo consistente na capacidade de autodeterminação. Os Estados federados são titulares tão só de autonomia, compreendida como governo próprio dentro do círculo de competências traçadas pela Constituição Federal (SILVA, 2014, p. 102).

Nesse contexto, podemos conceituar a federação, como uma união de Estados para a formação de um Estado único, onde as unidades federadas preservam parte da sua autonomia política, enquanto a soberania é transferida para o Estado federal. Isso é importante para o estudo do federalismo, pois, em hipótese alguma, a união pode perder a sua soberania. $\mathrm{O}$ federalismo é um modelo 
de Estado onde as entidades políticas federadas, detém um grau de autonomia política e econômica considerável, porém são submetidas a uma autoridade política central, que possui a soberania.

Assim sendo, a constituição é que dita a forma como as relações entre os indivíduos e o Estado se efetivarão, sendo através da lei, elaborada com anuência da população, que a estabelece direta ou indiretamente (a lei em sentido amplo e segundo a regra da maioria, que elege seus congressistas). O Brasil, portanto, é um Estado federal, em que a união, os estados-membros e os municípios, todos igualmente autônomos, ocupam, juridicamente, o mesmo plano hierárquico, devendo por isso, receber tratamento jurídico isonômico. A nossa federação é indissolúvel, portanto, nenhum dos entes políticos (união, estados, DF e municípios) pode romper o pacto federativo, ou seja, não podem se separar do vínculo federativo, pois não possuem essa autonomia. Esse princípio da indissolubilidade do pacto federativo (união indissolúvel dos estados, municípios e DF) veda aos Estados o direito de secessão.

A própria constituição permite, através do art. 34, inciso I, que em caso de qualquer tentativa de separação tendente a romper com a unidade da federação brasileira, é permitida a intervenção federal para manter a integridade nacional. Com isso, vislumbra-se que o princípio federativo é a forma de Estado, que se constitui a partir de uma união indissolúvel das organizações políticas autônomas, instituídas pela constituição de forma rígida.

Essa rigidez constitucional, no dizer de Dirley da Cunha Júnior (2011, p. 226) decorre da própria força normativa da constituição para vincular e impor os seus comandos, expressando em sua rigidez um processo complexo para modificação de suas normas. A par disso, temos um órgão constitucional incumbido do controle de constitucionalidade que é o Supremo Tribunal Federal, órgão do poder judiciário, cuja função é dizer o direito em caráter definitivo e com força constitucional do Estado.

Apesar disso, é marcante a característica de descentralização do nosso sistema federativo, cuja descentralização no dizer de Flávio de Azambuja Berti (2007, p. 27) corresponde a situação em que o poder público transfere a titularidade de sua competência, atribuída pela constituição, para outra entidade com personalidade jurídica própria, como exemplo, no âmbito administrativo, a administração indireta, através da criação de autarquias e fundações. Assim também, no âmbito político, a constituição confere poder para os entes políticos como estados-membros e municípios nos moldes dos fundamentos descritos no Art. $1^{\circ}$ e 18 . Isso garante uma maior descentralização do poder.

\section{PRINCÍPIO DO ESTADO DEMOCRÁTICO DE DIREITO}

O Estado Democrático de Direito reúne os princípios do Estado de Direito e o princípio da democracia. Isso, contudo, não é uma simples reunião 
formal dos respectivos elementos, mas, em verdade, constitui um conceito novo que os supera, na medida em que incorpora um componente revolucionário de transformação do status quo, os dois princípios clássicos (Silva, 2014, p. 114).

Gomes Canotilho (2003, p. 287) lembra que é conhecida a formulação de Lincoln quanto a 'essência' da democracia: "governo do povo, pelo povo e para o povo", que ainda hoje é considerada como a síntese mais lapidar dos momentos fundamentais do princípio democrático. Por isso designa como a fórmula de Lincoln como um modo de justificação positiva da democracia.

O princípio democrático acolhe os mais importantes postulados da teoria democrática representativa - órgãos representativos, eleições periódicas, pluralismo partidário, separação de poderes. Em segundo lugar, o princípio democrático implica democracia participativa, isto é, a estruturação de processos que ofereçam aos cidadãos efetivas possibilidades de aprender a democracia, participar nos processos de decisão, exercer controle crítico na divergência de opiniões (Canotilho, 2003, p. 288).

José Afonso da Silva (2014, p. 114) afirma que:

A democracia, como realização de valores (igualdade, liberdade e dignidade da pessoa) de convivência humana, é conceito mais abrangente do que o de Estado de Direito, que surgiu como expressão jurídica da democracia liberal. A superação do liberalismo colocou em debate a questão da sintonia entre o Estado de Direito e a sociedade democrática. A evolução desvendou sua insuficiência e produziu o conceito de Estado Social de Direito, nem sempre de conteúdo democrático. Chega-se ao Estado Democrático de Direito que a Constituição acolhe no art. $1^{\circ}$ como um conceito-chave do regime adotado, tanto quanto o são o conceito de Estado de Direito Democrático da Constituição da República Portuguesa (art. 2º) e o de Estado Social e Democrático de Direito da Constituição Espanhola (art. 10).

Esse princípio não se compadece com uma compreensão estática de democracia. Antes de tudo, é um processo de continuidade transpessoal, irredutível a qualquer vinculação do processo político a determinadas pessoas. A democracia é um processo dinâmico inerente a uma sociedade aberta e ativa, oferecendo aos cidadãos a possibilidade de desenvolvimento integral e de liberdade de participação crítica no processo político em condições de igualdade econômica, política e social (CANOTILHO, 2003, p. 289).

Nesse sentido, acrescenta Canotilho (2003, p. 98), o Estado de direito cumpria e cumpre bem as exigências que o constitucionalismo salientou relativamente à limitação do poder político. O Estado constitucional é, assim, e em primeiro lugar, o Estado com uma constituição limitadora do poder através do império do direito. Até a conciliação entre Estado de direito e democracia 
ocorreram muitas reticências, sendo que para alguns autores Estado de direito e democracia correspondem a dois modos de ver a liberdade. No Estado de direito concebe-se a liberdade como liberdade negativa, ou seja, uma 'liberdade de defesa' ou de 'distanciação' perante o Estado. Ao Estado democrático estaria inerente a liberdade positiva, isto é, a liberdade assente no exercício democrático do poder. É a liberdade democrática que legitima o poder.

Já o Estado constitucional é 'mais' do que Estado de direito. O elemento democrático não foi apenas introduzido para 'travar' o poder, foi também reclamado pela necessidade de legitimação do mesmo poder na soberania popular. Se quisermos um Estado constitucional assente em fundamentos não metafísicos, temos de distinguir claramente duas coisas: (1) uma é a da legitimidade do direito, dos direitos fundamentais e do processo de legislação no sistema jurídico; 2) outra é a da legitimidade de uma ordem de domínio e da legitimação do exercício do poder político (CANOTILHO, 2003, p. 100).

Assim sendo, Gilmar Antônio Bedin (2013, p. 2) assevera que a afirmação do estado de direito pressupõe uma clara distinção entre direito e poder e uma subordinação do poder ao direito. Por isso, é possível afirmar que a institucionalização do estado de direito tende a produzir, de forma geral, a eliminação do arbítrio no exercício dos poderes públicos, a submissão do poder ao império do direito e o reconhecimento de direitos e garantias fundamentais, que são, em última análise, a materialização de uma ideia de justiça presente na constituição do Estado.

A partir dessa constatação, o autor afirma que:

o Estado de Direito não é nenhuma das seguintes formas de Estado: a) não é um Estado que decreta leis arbitrárias, cruéis e desumanas; b) não é um Estado em que o Direito se identifica com as razões de Estado, impostas e estabelecidas pelos detentores do poder; c) não é um Estado pautado por radical injustiça na formulação e aplicação do Direito e por acentuada desigualdade nas relações da vida material (Canotilho, 1999a, b). Não se constituindo nenhuma destas formas de Estado, é importante reconhecer que o Estado de Direito é uma forma singular de configuração do Estado moderno (BEDIN, 2013, p. 3).

Essa singularidade é garantida, de acordo com Bedin (2013, p. 3), por dez dimensões essenciais: a) A primeira dimensão é que ele é um Estado subordinado ao império do direito; b) A segunda dimensão essencial é que o Estado de Direito é um Estado de direitos fundamentais; c) A terceira dimensão é que o Estado de Direito é um Estado que observa o princípio da razoabilidade; d) A quarta dimensão essencial é que o Estado de Direito é um Estado que estabelece o princípio da legalidade da administração pública em todas as suas esferas de atuação; e) A quinta dimensão é que o Estado de Direito é um Estado que responde pelos seus 
atos; f) A sexta dimensão essencial é que o Estado de Direito é um Estado que garante a via judiciária; g) A sétima dimensão é que o Estado de Direito é um Estado de segurança e de confiança das pessoas; h) A oitava dimensão essencial é que o Estado de Direito é um Estado estruturado a partir da divisão de poderes; i) A nona dimensão é que o Estado de Direito é um Estado de liberdade e de igualdade; j) A décima dimensão essencial é que o Estado de Direito é um Estado democrático e republicano.

No mesmo sentido, José Afonso da Silva (2014, p. 124) afirma que o Estado Democrático de Direito envolve os seguintes subprincípios políticosconstitucionais fundamentais:

a) Princípio da constitucionalidade, que exprime, em primeiro lugar, que o Estado Democrático de Direito se funda na legitimidade de uma Constituição rígida, emanada da vontade popular, que, dotada de supremacia, vincule todos os poderes e os atos deles provenientes, com as garantias de atuação livre de regras da jurisdição constitucional; b) Princípio democrático, que, nos termos da Constituição, há de constituir uma democracia representativa e participativa, pluralista, e que seja a garantia geral da vigência e eficácia dos direitos fundamentais (art. $1^{\circ}$ ); c) Sistema de direitos fundamentais, que compreende os individuais, coletivos, sociais e culturais (Títulos I, VII e VIII); d) princípio da justiça social, referido no art. 170, caput, e no art. 193, como princípio da ordem econômica e da ordem social; como dissemos, a Constituição não prometeu a transição para o socialismo mediante a realização da democracia econômica, social e cultural e o aprofundamento da democracia participativa, com o faz a Constituição portuguesa, mas com certeza ela se abre também, timidamente, para a realização da democracia social e cultural, sem avançar significativamente rumo à democracia econômica; e) princípio da igualdade (art. 50, "caput", e I); f) princípios da divisão de poderes (art. $2^{\circ}$ ) e da independência do juiz (art. 95); g) princípio da legalidade (art. $\left.5^{\circ}, \mathrm{II}\right) ;$ h) princípio da segurança jurídica (art. 5º XXXVI a LXXIII).

Nesse contexto, é possível afirmar ainda que o princípio do Estado Democrático de Direito transcende a ideia das particularidades de que constitui o estado de direito, pois abrange também o princípio da soberania popular, através do qual o povo é o titular do poder constituinte, que legitima o poder político. Configura-se assim, a exigência que todas as pessoas participem ativamente na vida política do país, pois o princípio da soberania popular está consagrado através do Art. 1º, parágrafo único, da Constituição de 1988.

Assim, fica evidente que o estado democrático de direito consiste numa estrutura que reforça a convivência humana em uma sociedade livre e solidária, regulada por leis justas, em que o povo é adequadamente representado, 
participando ativamente da organização social e política, permitida a convivência de ideias opostas e a liberdade de expressão. Dessa forma, é importante reiterar que o Brasil, em 1988, optou, por meio de sua nova constituição, por estatuir um Estado Democrático de Direito ao legitimar uma constituição democrática, fruto da vontade popular. Por isso, como menciona Luís Roberto Barroso (2009, p. 41), "no Brasil, a força normativa e a conquista de efetividade pela Constituição são fenômenos recentes, supervenientes ao regime militar, e que somente se consolidaram após a redemocratização e a promulgação da Constituição de 1988".

A nossa constituição atual deixa claro que a democracia faz parte da qualificação do Estado brasileiro, estendendo os seus valores sobre todos os elementos constitutivos da nossa ordem jurídica. Isso é visível pela posição topográfica ocupada pelo princípio democrático, expresso já no texto do artigo primeiro, dentre os demais princípios fundamentais. Com isso, o Estado Democrático de Direito se revela como uma opção fundamental do poder constituinte originário e destaca o ser humano ao centro de toda a estrutura jurídica, política e social de um país, seja o indivíduo como detentor de direitos civis e políticos como o indivíduo como titular de direito econômicos e sociais. Isso é fundamental e nos permite concluir que os princípios e valores consagrados constitucionalmente detêm força normativa e vinculante que se irradiam a todo o sistema jurídico, conformando a realidade social aos objetivos eleitos democraticamente pelo povo.

\section{CONSIDERAÇÕES FINAIS}

A Constituição Federal Brasileira de 1988 é, indubitavelmente, um marco na história constitucional do Brasil. Essa relevância deve-se ao fato de ser uma constituição democrática e popular. Promulgada no final do processo de abertura política, deu novos rumos a sociedade brasileira e se firmou como um documento legal de grande força normativa, apesar de seus enormes desafios.

Nesse contexto, ultrapassado mais de trinta anos da promulgação da atual constituição, denota-se que os princípios estruturantes nela estabelecidos continuam sempre atuais, ou seja, não 'envelhecem', não podem ser desconsiderados ou extintos, pois são os fundamentos da nossa sociedade e que devem ser observados para que o desenvolvimento do país possa ocorrer de forma justa e igualitária.

Como visto, o princípio republicano pontua não só a forma de governo, mas abrange toda a organização estatal e o relacionamento desta esfera com a sociedade. Isso é e continuará sendo importantíssimo, pois o Estado deve agir no interesse público, prestando satisfação de seus atos e não se guiando por interesses particulares.

O princípio da divisão de poderes, que a constituição inscreve como um dos princípios fundamentais que ela adota, está cada vez mais presente no nosso 
dia-a-dia, caracterizado pelas diversas discussões das demandas que envolvem os poderes da União: o Legislativo, o Executivo e o Judiciário. A questão da independência e harmonia entre os poderes está cada vez mais em voga.

No mesmo sentido, o princípio da federação, fundamental eimprescindível, pois define a forma e a organização do Estado brasileiro, cujo objetivo principal é a autonomia entre os entes federados, porém, a unicidade nacional para caracterizar o Brasil perante o direito internacional, também é objeto de debates e discussões nos dias atuais, principalmente diante das políticas públicas destinadas a viabilização da sociedade brasileira e a relação com os diversos países do mundo.

Por fim, temos o princípio do Estado Democrático de Direito. Esse princípio, que reúne os princípios do Estado de Direito e o princípio da democracia, tem uma importância fundamental. Isso porque é essa estrutura que permite a convivência humana pacífica e aponta para a construção de uma sociedade livre, justa e solidária, tendo como fundamento a soberania popular.

Conjunto de princípios, como se pode ver, fundamentais para o presente e o futuro do Brasil. Assim, apesar das crises circunstanciais, é um dever de todos os democratas lutar pela sua manutenção e pela sua eficácia transversal na ordem jurídica brasileira. Para isso, é fundamental a defesa da força normativa da constituição e sua apropriação pelos juristas e pela sociedade.

\section{REFERÊNCIAS}

ATALIBA, Geraldo. República e Constituição. 2a ed. São Paulo: Malheiros, 2004.

BEDIN, Gilmar Antonio. Estado de direito: tema complexo, dimensões essenciais e conceito. Direito em Debate. Ijuí, ano XXII, n. 39, p. 144-152, jan-jun. 2013.

BERTI. Flávio Azambuja. Direito Tributário e Princípio Federativo. São Paulo: Quartier Latin, 2007.

BRASIL. Constituição da República Federativa do Brasil de 1988. http://www.planalto.gov. br/ccivil_03/constituicao/constituicao.htm.

CANOTILHO, José Joaquim Gomes. Direito Constitucional. $5^{\text {a }}$ ed. São Paulo: Almedina, 2003.

CARRAZZA, Antônio Roque. Curso de direito tributário. 27 ed. São Paulo: Malheiros, 2011.

COMPARATO, Fábio Konder. O desafio de construir um novo poder. Disponível em: $<$ http://www. corecon-rj.org.br/artigos_det.asp?Id_artigos=32>. Acesso em: 27 jan. 2019.

CUNHA JÚNIOR, Dirley da. Curso de Direito Constitucional. $4^{a}$ ed. Salvador: JusPodivm, 2010. 
LAFER, Celso. O significado de república. Estudos históricos, Rio de Janeiro, vol. 2, n. 4, p. 214-224, 1989.

MONTESQUIEU, Charles de Secondat Baron de. O Espírito das Leis. Introdução, trad. e notas de Pedro Vieira Mota. $7^{\text {a }}$ ed. São Paulo, Saraiva: 2000.

RIBEIRO, Renato Janine. A República. 2a ed. São Paulo: Publifolha, 2008.

SILVA, José Afonso da. Curso de direito constitucional positivo. 37 ed. rev. e atual até EC nº 76/2013. São Paulo: Malheiros, 2014.

Submetido: 30/10/2019

Aceito: 21/11/2019 


\title{
A CONSTITUIÇÃO BRASILEIRA DE 1988 E SEUS PRINCÍPIOS ESTRUTURANTES
}

\begin{abstract}
Resumo
A Constituição de 1988 possui muitas características específicas. O mais importante é que a mesma é uma constituição cidadã. Essa condição é garantida por vários pressupostos específicos. Um desses pressupostos são os princípios estruturantes acolhidos pelo texto constitucional e que fundamentam atualmente toda a estrutura da ordem jurídica brasileira em vigor. Nesse sentido, são fundamentais os princípios da república, o princípio da federação, o princípio da divisão dos poderes e o princípio do Estado Democrático de Direito. O objetivo do texto é apresentar os referidos princípios e seus contornos institucionais. O método de pesquisa utilizado na elaboração do trabalho foi o hipotéticodedutivo e a técnica de pesquisa utilizada foi a da pesquisa bibliográfica.
\end{abstract}

Palavras-chave: Constituição de 1988. Princípios Fundamentais. Democracia. 


\title{
THE 1988 BRAZILIAN CONSTITUTION AND ITS STRUCTURING PRINCIPLES
}

\begin{abstract}
The 1988 Constitution has many specific characteristics. The most important thing is that it is a citizen's constitution. This condition is guaranteed by several specific assumptions. One of these assumptions is the structuring principles embraced by the constitutional text and which currently underlie the entire structure of the Brazilian legal order in force. In this sense, the principles of the republic, the principle of federation, the principle of the division of powers and the principle of the democratic rule of law are fundamental. The purpose of the text is to present these principles and their institutional outlines. The research method used in the preparation of the work was hypothetical-deductive and the research technique used was that of bibliographic research.
\end{abstract}

Keywords: 1988 Constitution. Fundamental Principles. Democracy. 